\title{
Bioavailability of immediate and controlled release formulations of lithium carbonate
}

\section{Biodisponibilidade de formulações de liberação imediata e controlada de carbonato de lítio}

\author{
Luciana Vismari, Maria Laura N Pires, Ana Amélia Benedito-Silva and Helena Maria Calil \\ Department of Psychobiology, Federal University of São Paulo (Unifesp/EPM). São Paulo, SP, Brazil
}

Abstract Introduction/Objectives: Controlled-release lithium formulations were developed to minimize elevated blood peaks, related to side-effects and intoxications. However, there is little information about the bioavailability of the only controlled-release lithium formulation available in Brazil. The objective of this study was to compare the bioavailability of controlled-release and immediate-release lithium formulations, after single and multiple doses. Methods: Twelve healthy volunteers received $900 \mathrm{mg}$ of immediate-release or controlled-release lithium carbonate in single or multiple doses during 9 days. After single dose administration, the following parameters were analyzed for each formulation: maximum lithium concentration $\left(\mathrm{C}_{\max }\right)$; time to reach $\mathrm{C}_{\max }\left(\mathrm{t}_{\max }\right)$; area under the curve of serum concentration versus time $\left(\mathrm{AUC}_{0-12}\right.$ and $\left.\mathrm{AUC}_{0-\infty}\right)$ and the elimination half-life $\left(\mathrm{t}_{1 / 2 \text { elim. }}\right)$. After multiple doses, $\mathrm{C}_{\max }$; $\mathrm{t}_{\text {max }} ; \mathrm{AUC}_{0-12} ;$ mean $\left(\mathrm{C}_{\text {mean }}\right)$ and minimum drug concentration $\left(\mathrm{C}_{\text {min }}\right)$ and degree of fluctuation (DF) were analyzed. A $90 \%$ confidence interval $(90 \% \mathrm{CI})$ for the ratio between the AUCs for each formulation was constructed.

Results/Discussion: Following single dose, the two formulations were bioequivalent; however, they were not after multiple doses. This fact could be a consequence of methodological limitations of lithium level's measurements since, following single dose, these levels could not be detected at time periods 24 and $48 \mathrm{~h}$ in many volunteers, compromising the calculation of $\mathrm{t}_{1 / 2 \text { elim }}$, and consequently of the $\mathrm{AUC}_{0-\infty}$ and the $90 \% \mathrm{CI}$ to the ratio of these areas. Therefore, the bioequivalence found after single dose may be an unreliable result.

Keywords Lithium carbonate. Bioavailability. Dosage forms. Single dose. Doses repetition. Healthy man.

Resumo Introdução/Objetivo: Formulações de liberação controlada de lítio foram produzidas para minimizar picos sangüíneos elevados relacionados a efeitos colaterais e intoxicações. No entanto, o único produto com liberação controlada de lítio disponível no Brasil possui poucas informações a respeito de sua biodisponibilidade. O presente estudo tem como objetivo comparar a biodisponibilidade de formulações de liberação imediata e controlada de carbonato de lítio, após administração de doses única e múltiplas.

Métodos: Voluntários sadios ( $\mathrm{n}=12)$ receberam $900 \mathrm{mg}$ de carbonato de lítio de liberação imediata ou controlada, em dose única ou durante nove dias. Após dose única, foram analisados, para cada formulação, concentração sangüínea máxima de lítio $\left(\mathrm{C}_{\text {máx }}\right)$, tempo para atingir essas concentrações $\left(\mathrm{t}_{\text {máx }}\right)$, área sob a curva da concentração sangüínea versus tempo ( $\mathrm{ASC}_{0-12}$ e $\mathrm{ASC}_{0-\infty}$ ) e tempo de meia-vida de eliminação $\left(\mathrm{t}_{1 / 2 \text { elim }}\right.$ ). Após doses múltiplas, $\mathrm{C}_{\text {máx }}$, $\mathrm{t}_{\text {máx }}, \mathrm{ASC}_{0-12}$, concentração sangüínea média $\left(\mathrm{C}_{\text {médio }}\right)$ e mínima $\left(\mathrm{C}_{\min }\right)$ de lítio e porcentagem de flutuação dessas concentrações $(\% \mathrm{~F})$ foram calculadas. Calculou-se um intervalo de confiança de 90\% (IC90\%) para a razão entre as ASC de cada formulação.

Resultados/Discussão: Após dose única, as duas formulações mostraram-se bioequivalentes; no entanto, não o foram após doses múltiplas. Esse fato talvez decorra das limitações do método de determinação da litemia, uma vez que, após dose única, as concentrações nos períodos de tempo 24 e 48 horas não foram detectáveis para muitos voluntários, prejudicando o cálculo do $\mathrm{t}_{1 / 2 \text { elim. }} \mathrm{e}$, conseqüentemente, o da $\mathrm{ASC}_{0-\infty}$ e do IC90\% para a razão dessas áreas. Logo, a bioequivalência encontrada após dose única pode não ser um resultado confiável.

Descritores Carbonato de lítio. Biodisponibilidade. Formas de dosagem. Dose única. Repetição de doses. Homem são.

\footnotetext{
Sponsored by the CNPq (Processes ns. 132203/98-7 and 301596/79-4 - National Research Council Master and Researcher I Grants) and from the Association Fund of Incentive to Psychopharmacology (AFIP). Part of the Master thesis "Study on the Bioavailability and Chronobiology of Lithium in Healthy Volunteers", presented to the Department of Psychobiology of the Unifesp/EPM, 2000.

This study was partially presented as a poster in the Brazilian Congress of Psychiatry in the city of Fortaleza, state of Ceará, in October 1999. Received on 25/9/2001. Reviewed on 21/1/2002. Approved on 31/1/2002.
} 


\section{Introduction}

The prophylactic-therapeutic action of lithium salts in bipolar disorder has been confirmed by many studies in several

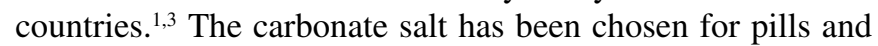
capsules, as it is less hygroscopic and less irritating to the gastric mucosa than others, especially chloride. ${ }^{4}$ It is commercially available in immediate-release formulations. However, this kind of formulation produces high lithium blood levels, which have been associated to side effects and intoxication originated from the product. ${ }^{5}$

Alternatively, the modified or controlled-release formulations provide specific advantages over immediate-release formulations, due to decreased blood peaks secondary to a showed absorption rate. The elimination phase of the drug's decreasing curve is altered, causing an increase in the elimination half-life, allowing to the administration of a daily single dose instead of the traditional divided doses - two or three (b.i.d. or t.i.d.)-, diminishing the chance of patients forgetting the drug, and increasing their compliance. Besides, the chance of survival after an overdose rises as there is more time for a gastric lavage before the plasmatic concentration reaches its peak value. ${ }^{6-8}$

There have been several studies comparing the bioavailability of the controlled-release formulations existent in the world market. ${ }^{9-11}$ Nevertheless, there is scarce information about the bioavailability of the only product with controlled-release lithium available in Brazil. ${ }^{12}$

The objective of this study is to compare the bioavailability of controlled and immediate-release formulations of lithium carbonate (Carbolithium CR $450 \mathrm{mg}$ and Carbolithium $300 \mathrm{mg}$; Eurofarma Laboratórios Ltda, SP, Brazil) after administration of single and multiple (nine days) doses to healthy volunteers.

\section{Materials and Methods}

Twelve healthy, Caucasian, male volunteers (aging 18 to 30), selected through an advertisement in the premises of the Federal University of São Paulo (Unifesp) participated in the study. The Institution's Research Ethics Committee previously approved the study. The volunteers gave written informed consent before beginning the study. They all went through physical and psychiatric assessment, with the Structured Clinical Interview for the DSM-IV axis I disorders - non- patient edition $^{13}$ and routine laboratory tests (hemogram, creatinine, uric acid, glutamic oxalacetic transaminase [GOT], glutamic piruvic transaminase [GPT], thyroid-stimulating hormone [TSH], free tetraiodothyronine $\left[\mathrm{T}_{4}\right]$, cholesterol, triglycerids, urea, glucose and magnesium, sodium, potassium and chlorine). The presence of any result with a clinically significant deviation from the normality was an exclusion criterion.

The volunteers were instructed to abstain from consuming alcohol, drugs and any other kind of medications during the study's period.

We used immediate-release lithium carbonate (Carbolithium $300 \mathrm{mg}$ - lot 016.98), and controlled-release (Carbolithium CR $450 \mathrm{mg}$ - lot 004.98) formulations, donated by Eurofarma Laboratórios Ltda (SP, Brazil).
The study consisted in a two-phase cross-over study (I: single dose and II: multiple doses) in which the 12 volunteers were randomically divided in two groups (A and B). They were instructed to fast for 10 hours before the beginning of the procedure and 4 hours after drug administration. In phase $\mathrm{I}$, the volunteers received $900 \mathrm{mg}$ of lithium carbonate as a single dose at 8:00h A.M. (group A: immediate release formulation and group B controlled-release formulation). Blood samples $5 \mathrm{ml}$ were collected immediately before the ingestion of the drug (time 0 ) and after the time intervals $0.5,1,1.5,2,3$, $4,6,8,12,24$ and 48 hours. A week after, the procedure was repeated, and treatments were alternated.

In phase II, both groups of volunteers (A and B) received 900 $\mathrm{mg}$ /day of lithium carbonate during nine days. Group A received 2 immediate-release pills at 8:00 A.M. and 1 pill at 08:00 P.M., and group B received 1 controlled-release pill at 8:00 A.M and other at 08:00 P.M. Blood samples were collected on the eighth day of treatment, immediately before the morning ingestion of the drug (time zero) and afterwards in the same time intervals $(0.5,1,1.5,2,3,4,6,8,12,24$ and 48). The blood lithium was determined in triplicate with the ion-selective electrode technique (EasyLyte $\mathrm{Na} / \mathrm{K} / \mathrm{Cl} / \mathrm{Li}$ Analyzer - Medica Corporation, Massachusetts, USA).

Pharmacokinetic parameters were determined according to the rules of the Food and Drug Administration (FDA), ${ }^{14}$ of the United States Pharmacopeia ${ }^{15}$ and of the National Sanitary Vigilance Agency from Brazil. ${ }^{16}$

- Phase I - single dose: AUC: area under the curve (in $\mathrm{mEq} . \mathrm{h} / \mathrm{l})$ delineated by the drug's concentration versus time, calculated by the trapezoidal method from time zero to time $12 \mathrm{~h}\left(\mathrm{AUC}_{0-\mathrm{t}}\right)$ and extrapolated to infinitum (AUC $\left.{ }_{\infty}\right) ; \mathrm{t}_{1 / 2}$ : elimination half-life time, corresponds to the time needed for a drug to reach half of the initial blood concentration; $\mathrm{C}_{\max }$ : corresponds to the maximum lithium concentration, in $\mathrm{mEq} . / \mathrm{l}$, directly obtained from individual curves of concentration vs. time; $\mathrm{T}_{\max }$ : refers to the time, in hours, in which $\mathrm{C}_{\max }$ was achieved. This value was directly obtained from individual curves of blood concentration vs. time.

- Phase II-multiple doses: $\mathrm{AUC}_{0-12} ; \mathrm{C}_{\max } ; \mathrm{T}_{\max } ; \mathrm{C}_{\min }$ : drug concentration at the end of each interval between doses, in the steady state, directly obtained from the graph of blood concentration vs. time for each subject, in $\mathrm{mEq} / \mathrm{l}$; $\mathrm{C}_{\text {mean }}$ : mean drug concentration $(\mathrm{mEq} / \mathrm{l})$ in the steady state, obtained by the equation: $\mathrm{C}_{\text {mean }}=\left(\mathrm{AUC}_{0-\mathrm{t}}\right) / \tau$, where $\tau$ corresponds to the interval between doses (in this case, 12 hours); \%F: the degree of fluctuation of drug concentrations, calculated by the equation: $\% \mathrm{~F}=\left[\left(\mathrm{C}_{\text {máx }}-\right.\right.$ $\left.\left.\mathrm{C}_{\text {min }}\right) / \mathrm{C}_{\text {mean }}\right] \times 100 \%$.

The AUC parameter was used to obtain the $90 \%$ confidence interval $(90 \% \mathrm{CI})$ for the differences of means between controlled-release and immediate-release products, transformed into the Neperian logarithm $(\mathrm{ln})$. As this is a study with a controlledrelease product, this conclusion does not take into account the confidence interval obtained for $\mathrm{C}_{\max }$, as this is intentionally modified in this kind of formulation. Two drug formulations are 
considered bioequivalent when the antilogs of the $90 \%$ CIs for the ratios of AUC means fall between 0.8 and 1.25.

The parameters $\mathrm{AUC}_{0-\mathrm{t}}$ and $\mathrm{C}_{\max }$ were submitted to analysis of variance (ANOVA) to assess if there were effects formulation's order of administration of the i.e., of phase (I and II) and of treatment (immediate and controlled-release).

The other pharmacokinetic parameters of immediate and controlled-release formulations were compared with paired t test, except for the $\mathrm{T}_{\max }$, for which it has been recommended a nonparametric analysis (Wilcoxon's test). ${ }^{17}$

The assessment of adverse effects of the two lithium carbonate formulations was performed by a Side Effects Scale, developed by the researchers and composed of the 21 main adverse effects cited in the literature for this drug. For each of them, the volunteer should choose the option that better described its intensity at the moment, which varied from the degree zero (absence of effect) to 3 (great effect). This scale was administered in phase I (before the drug administration and 3, 6 and 12 hours after it) and in phase II (before the beginning of the treatment and after eight days).

\section{Results}

The sample was composed by 12 healthy, young (age $23.7 \pm 3.4$ ), male volunteers with a mean body mass of $74.7 \pm 9.6$ $\mathrm{Kg}$, mostly students or employees in the University.

During phase I (single dose administration), lithium blood levels in several collecting time-points were under the assay's sensitivity level $(0.2 \mathrm{mEq} / \mathrm{l})$. Therefore, only in 7 out of 12 collections the concentrations were detectable in all volunteers: time 0 (before the ingestion of lithium, considered as blood lithium zero) and 2, 3, 4, 6, 8 and 12 hours after the drug administration.

A three-way ANOVA revealed absence of order effects(firstly immediate or controlled release) or treatment (controlled or immediate-release formulations) in the measurements of AUC $(\mathrm{F}=0.11$ and 1.48, respectively, $\mathrm{p}>0.05)$ and $\mathrm{C}_{\text {max }}(\mathrm{F}=0.66$ and 4.50 , respectively; $\mathrm{p}>0.05$ ), but a significant phase effect (single or multiple doses) in $\mathrm{AUC}_{0-\mathrm{t}}$ and $\mathrm{C}_{\text {max }}(\mathrm{F}=91.5$ and 36.51 ; respectively, $\mathrm{p}<0.001)$. The ANOVA also revealed a significant interaction between phase and treatment for $\mathrm{AUC}(\mathrm{F}=147.6 ; \mathrm{p}<0.001)$ and $\mathrm{C}_{\text {max }}(\mathrm{F}=48.96 ; \mathrm{p}<0.001)$.

Data analysis from phase I (single dose) showed that the controlled-release formulation produced smaller $\mathrm{AUC}_{0-12}$ and $\mathrm{C}_{\max }$ when compared to the immediate-release formulation (Table 1). However, there was no difference between the formulations' $\mathrm{AUC}_{0-\infty}$, since the $90 \% \mathrm{CI}$ for the mean differences between formulations was into the values pre-established by the FDA (0.8 to 1.25). The statistical analysis of the remaining parameters showed that the controlled-release formulation produced a significantly higher $\mathrm{T}_{\max }$ than the immediate-release formulation $(z=2.803, p<0.01)$, but the $t_{1 / 2 \text { elim. }}$ was not different for both formulations $(\mathrm{t}=-1.37 ; \mathrm{p}>0.05)$.

The values (mean \pm standard deviation) of the curve of lithium concentration versus time in healthy volunteers after a 900-mg single dose of immediate and controlled-release lithium carbonate are in Figure 1. The individual curves pro-
Table 1 - Phamacokinetic parameters (mean \pm standard deviation) and confidence intervals obtained after administration of an immediate and controlled-release single dose of $900 \mathrm{mg}$ of lithium carbonate in healthy volunteers $(n=12)$.

\begin{tabular}{lccc}
\hline $\begin{array}{l}\text { Pharmacokinetic } \\
\text { parameters }\end{array}$ & $\begin{array}{c}\text { Immediate-release } \\
\text { formulation }\end{array}$ & $\begin{array}{c}\text { Controlled-release } \\
\text { formulation }\end{array}$ & IC90\%* \\
\hline $\mathrm{C}_{\max }(\mathrm{mEq} / \mathrm{l})$ & $0.85 \pm 0.12$ & $0.59 \pm 0.13^{\star *}$ & \\
$\mathrm{AUC}_{0-12}(\mathrm{mEq} . \mathrm{h} / \mathrm{l})$ & $5.99 \pm 0.83$ & $4.71 \pm 0.68$ & $0.73-0.85$ \\
$\mathrm{AUC}_{0-\infty}(\mathrm{mEq} \cdot \mathrm{h} / \mathrm{l})$ & $24.65 \pm 7.92$ & $24.71 \pm 4.28$ & $0.89-1.24$ \\
$\mathrm{~T}_{\max }(\mathrm{h})$ & $2.42 \pm 0.85$ & $4.59 \pm 1.61^{\star \star \star}$ & \\
$\mathrm{t}_{1 / 2 \text { elim. }}(\mathrm{h})$ & $34.25 \pm 10.75$ & $39 \pm 6.71^{\star \star \star \star}$ &
\end{tabular}

*Lower Limit (LL) and Upper Limit (UL) of the $90 \%$ confidence interval for the mean difference between both formulations, calculated using data transformed into logarithm;

${ }^{*}$ Duncan's test, $p<0.05$;

***Wilcoxon's test (non parametric), $p<0.01$;

${ }^{\star \star * \star *}$ paired t test, $p>0.05$

duced by both formulations are in Figure 2. It is noteworthy that volunteers $4,6,8,11$ and 12 showed very similar or even equal $\mathrm{T}_{\max }$ values for both formulations. Regarding the $\mathrm{C}_{\max }$ produced by both products, they were similar in volunteers 4 and 11 .

The data analysis of Phase II (multiple-dose administration) revealed that both formulations were similar as regards the $\mathrm{C}_{\max }$ (Table 2). However, the time to reach the maximum concentration, or $\mathrm{T}_{\max }$, was longer after the administration of the controlledrelease formulation. Formulations also differed as concerns the $\mathrm{AUC}_{0-12}$, since the confidence interval for mean differences between formulations was not within the limits pre-established by the FDA (0.8 to 1.25). For the remaining parameters, the controlled-release formulation produced a higher mean minimum blood concentrations of the drug than the immediate-release formulation, with a lower percentage of concentration fluctuation $(\% \mathrm{~F})$ along the day. The values (mean \pm standard deviation) of the curve of blood lithium concentration versus time in healthy volunteers $(n=12)$ after multiple doses of immediate-release (Carbolithium $300 \mathrm{mg}$ ) and controlled-release (Carbolithium CR $450 \mathrm{mg}$ ) lithium carbonate for 9 days are in Figure 3, whereas the individual curves of these formulations are in Figure 4. It is noteworthy that volunteers $6,10,11$ and 12 showed similar $\mathrm{T}_{\max }$ values for both formulations. As for lithium blood concentrations in volunteer 12 , they did not vary over time after the administration of controlled-release formulation.

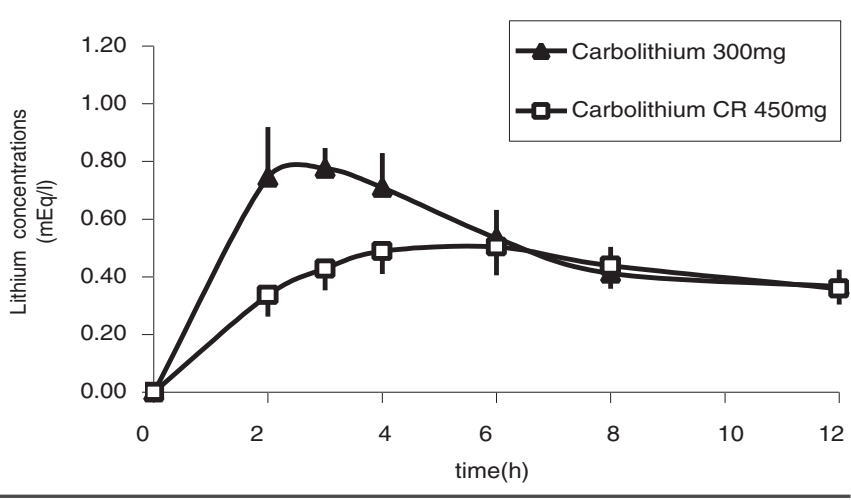

Figure 1 - Lithium serum concentrations (mean \pm standard deviation) versus time in healthy volunteers $(n=12)$ after $900 \mathrm{mg}$ of immediate (Carbolithium $300 \mathrm{mg}^{\circledR}$ ) and controlled-release (Carbolithium CR $450 \mathrm{mg}^{\circledR}$ ) lithium carbonate in single dose. 

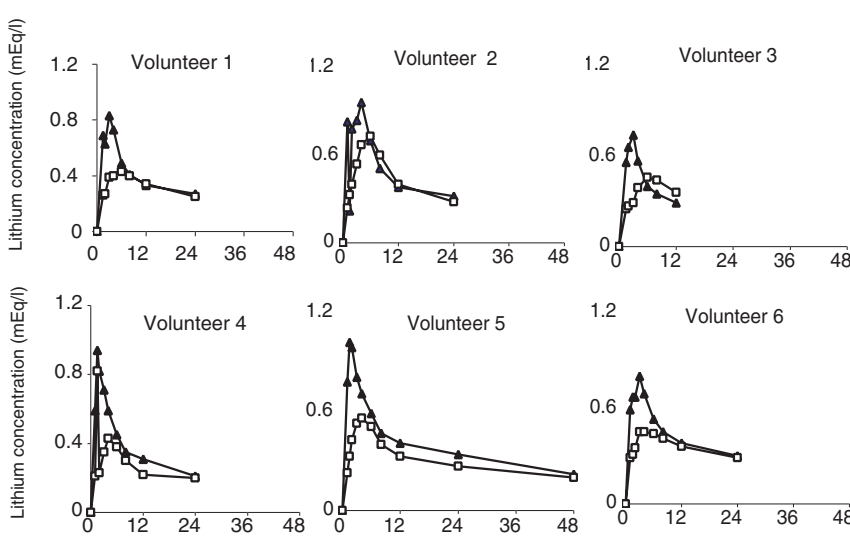

1.2 Volunteer 6
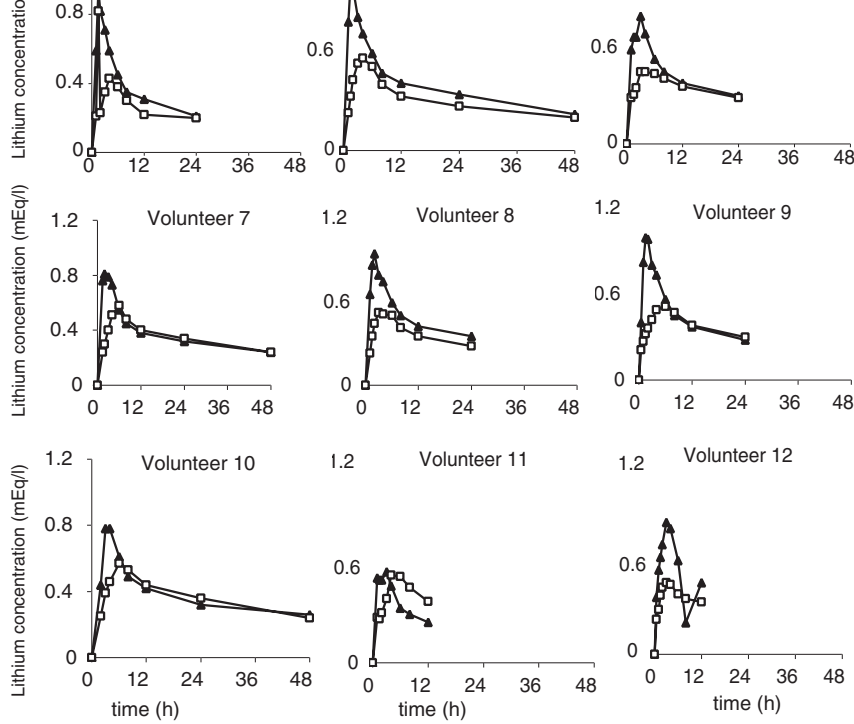

Figure 2 - Lithium serum concentrations versus time in healthy volunteers $(n=12)$ after $900 \mathrm{mg}$ of immediate $\left(\Delta\right.$ : Carbolithium $\left.300 \mathrm{mg}^{\oplus}\right)$ and controlled-release ( $\square$ : Carbolithium CR $450 \mathrm{mg}{ }^{\circledR}$ ) lithium carbonate in single dose.

\section{Analysis of the Side-Effects Scale}

The reports recorded in the Side-Effects Scale show that eight volunteers had softened stools after a single dose of controlled-release formulation and only two of them after the administration of the immediate-release formulation. The report of softened stools was also the most important effect during the administration of multiple doses, having been reported by five volunteers who received the controlled-release formulation and by two volunteers who received the immediate-release formulation. Some volunteers also described sleep alterations $(n=6)$, irritability $(n=2)$ or abdominal pain $(n=4)$, which occurred more frequently with both formulations in the beginning of the treatment ( 3 or 4 days).

Table 2 - Pharmacokinetic parameters (mean \pm standard deviation) and confidence intervals obtained after administration of multiple doses (9 days) of $900 \mathrm{mg} /$ day of immediate and controlled-release lithium carbonate in healthy volunteers $(n=12)$.

\begin{tabular}{lccc}
\hline $\begin{array}{l}\text { Pharmacokinetic } \\
\text { parameters }\end{array}$ & $\begin{array}{c}\text { Immediate-release } \\
\text { formulation }\end{array}$ & $\begin{array}{c}\text { controlled-release } \\
\text { formulation }\end{array}$ & IC90\%* \\
\hline $\mathrm{C}_{\text {max }}(\mathrm{mEq} / \mathrm{l})$ & $0.99 \pm 0.20$ & $1.05 \pm 0.18$ & \\
$\mathrm{AUC}_{0-12}(\mathrm{mEq} \cdot \mathrm{h} / \mathrm{l})$ & $8.63 \pm 1.82$ & $10.44 \pm 1.92$ & $1.15-1.28$ \\
$\mathrm{~T}_{\text {max }}(\mathrm{h})$ & $1.83 \pm 0.64$ & $3.85 \pm 0.41^{\star \star}$ & \\
$\mathrm{C}_{\text {mean }}(\mathrm{mEq} / \mathrm{l})$ & $0.72 \pm 0.15$ & $0.87 \pm 0.16^{\star \star *}$ & \\
$\mathrm{C}_{\text {min }}(\mathrm{mEq} / \mathrm{l})$ & $0.55 \pm 0.13$ & $0.73 \pm 0.18^{\star \star *}$ & \\
$\% \mathrm{~F}(\%)$ & $61.16 \pm 15.31$ & $40.45 \pm 30.42^{\star \star *}$ &
\end{tabular}

${ }^{*}$ Lower limit (LL) and Upper limit (UP) of the $90 \%$ confidence interval for the mean difference between both formulations, calculated using data transformed into Neperian logarithm.

**Wilcoxon's test, $p<0.01$.

${ }_{* \star *}$ paired t test, $p<0.03$

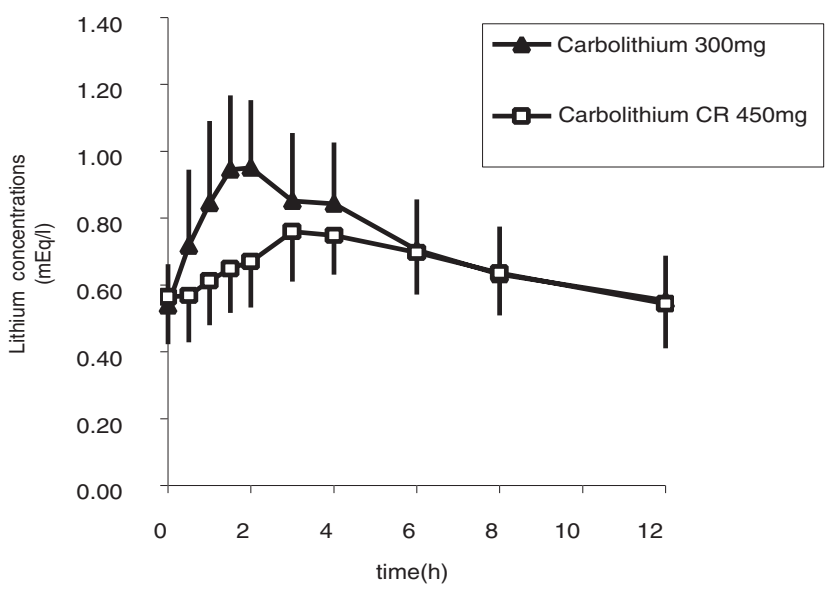

Figure 3 - Lithium serum concentrations (mean \pm standard deviation) versus time in healthy volunteers $(n=12)$ who received $900 \mathrm{mg}$ of immediate (Carbolithium $300 \mathrm{mg}^{\circledR}$ ) and controlled-release (Carbolithium CR $450 \mathrm{mg}^{\circledR}$ ) lithium carbonate in multiple doses.
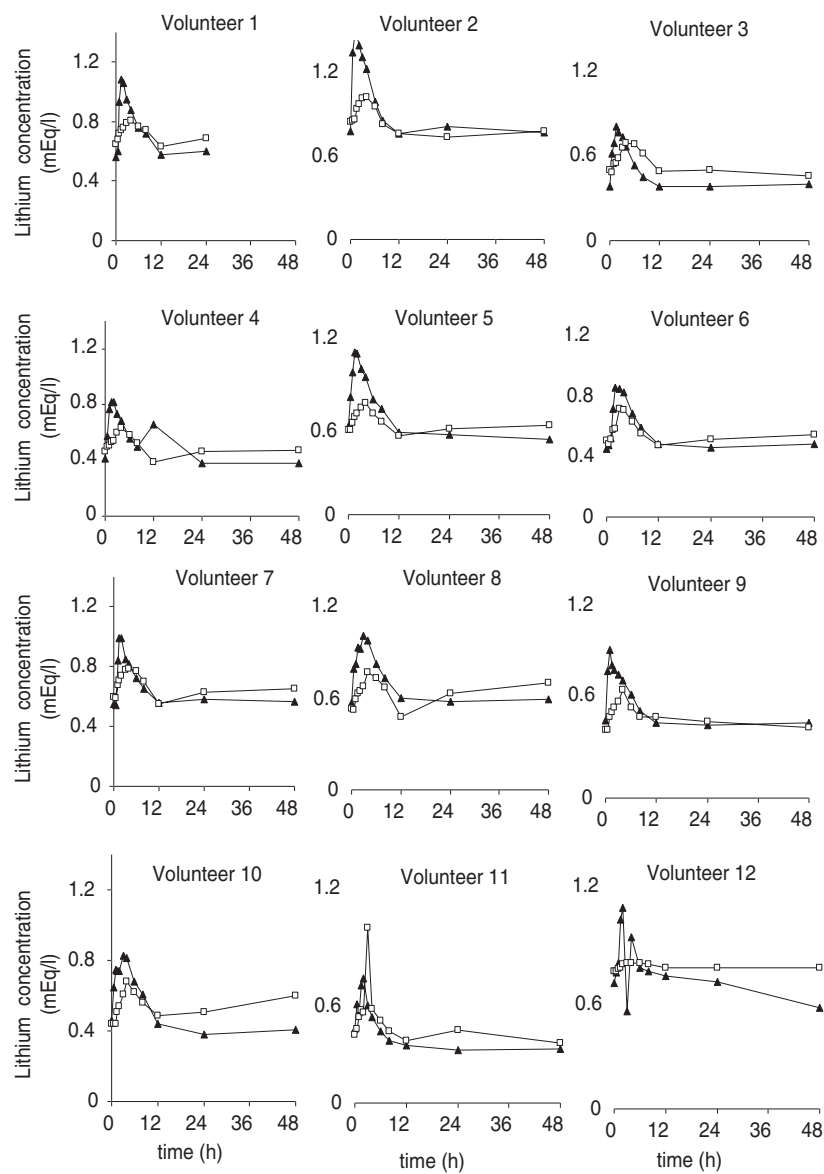

Figure 4 - Lithium serum concentrations versus time in healthy volunteers $(n=12)$ who received $900 \mathrm{mg} /$ day of immediate $\left(\Delta\right.$ : Carbolithium $\left.300 \mathrm{mg}^{\circledR}\right)$ and controlled-release ( $\square$ : Carbolithium CR $450 \mathrm{mg}{ }^{\circledR}$ ) lithium carbonate in multiple doses (9 days).

\section{Discussion}

The results of the study allow us to state that after a single dose both formulations were bioequivalent regarding the drug amount in the body in the time interval zero extrapolated to 
infinitum. After a single dose the $\mathrm{C}_{\max }$ of the controlled-release formulation was significantly lower than that of the immediate-release. $\mathrm{T}_{\max }$ of controlled-release formulation was significantly longer than that of immediate release. These results are in accordance with the profile of a controlled-release drug, i.e., the production of lower blood concentrations in a longer time interval after the drug administration.

The elimination half-life time after the single dose treatment with controlled-release lithium carbonate (Carbolithium CR $450 \mathrm{mg}$ ) and the immediate-release (Carbolithium $300 \mathrm{mg}$ ) formulations did not differ $\left(\mathrm{t}_{1 / 2 \mathrm{elim}}\right.$ : controlled-release $=39 \pm 6.71$; immediate-release $=34.25 \pm 10.75$ ). However, it was expected that the controlled-release formulation would have a higher $t_{1 / 2 \text { elim }}$, allowing to a decreased frequency of the treatment administration. ${ }^{6}$ A possible explanation for this result is that during this study phase (single dose), due to the fact that some volunteers' lithium blood after 24 hours were under the assay's lower detection limit $(0.2 \mathrm{mEq} / \mathrm{L})$, their values have not been measured and, therefore, have been considered as absence of lithium. Thus, the determination of the elimination rate constant $\left(\lambda_{\mathrm{z}}\right)$, which is calculated based on the individual curve of the plasma concentration vs. time was compromised as well as the determination of the $\mathrm{T}_{1 / 2 \mathrm{elim}}\left(\mathrm{T}_{1 / 2 \mathrm{elim}}=(\ln 2) / \lambda_{\mathrm{z}}\right)$.

After multiple doses of immediate and controlled-release lithium carbonate formulations there were no bioequivalence, as the $90 \% \mathrm{CI}$ for the $\mathrm{AUCs}_{0-12}$ was 1.15 - 1.28. The controlledrelease formulation produced minimum $\left(\mathrm{C}_{\min }\right)$ and mean $\left(\mathrm{C}_{\text {mean }}\right)$ serum lithium concentrations significantly higher than those of the immediate-release formulation, and a lower fluctuation of concentrations $(\% \mathrm{~F})$. Knowing that the fluctuation is a measure of the effectiveness of sustained released formulation, ${ }^{5,10}$ which has been usually related to a lower incidence of sideeffects, the results indicate that the controlled-release formulation could be a safe alternative for the patients' treatment. However, both formulations were similar regarding the maximum concentration produced, the opposite to what was expected for

\section{References}

1. Goodwin FK, Zis AP. Lithium in the treatment of mania: comparisons with neuroleptics. Arch Gen Psychiatr 1979;36:840-4.

2. Schou M. Lithium treatment of manic-depressive illness: a practical guide. 2nd.ed. New York: Karger; 1983.

3. Schou M. Forty years of lithium treatment. Arch Gen Psychiatry 1997;54:9-23.

4. Baldessarini RJ. Drugs and the treatment of psychiatric disorders: depression and mania. In: Hardman JG, Limbird LE. Goodman \& Gilman's "The pharmacological basis of therapeutics". 9th.ed. New York: MacGraw-Hill; 1996. p. 446-9.

5. Caldwell HC, Westlake WJ, Schriver RC, Bumbier EE. Steady-state lithium blood level fluctuations in man following administration of a lithium carbonate conventional and controlled-release dosage form. J Clin Pharmacol 1981;21:106-9.

6. Shelley R, Silverstone T. Lithium preparations. In: Johnson FN. Depression \& mania: modern lithium therapy. Oxford: IRL Press; 1987. p. $94-8$. this kind of product. This may be due to the fact that multiple doses of the controlled-release formulation had produced a high incidence of diarrhea, thus leading to sodium loosening in the feces and a consequent lithium retention, as these ions tend to maintain an equilibrium. This might have raised the blood levels of this drug, producing a higher $\mathrm{C}_{\text {max }}$. However, there was no alteration in the $\mathrm{T}_{\max }$, and the controlled-release formulation continued to produce $\mathrm{C}_{\text {max }}$ after a longer administration time than the immediate-release formulation.

Although lithium has a linear pharmacokinetics with the doses clinically used, the results of the current study showed differences in the bioequivalence after single and multiple doses of both formulations. Possibly the bioequivalence observed after the single dose stems from the problem occurred with levels of detection of lithium after 24 hours in some volunteers. This may have compromised the correct determination of the $\mathrm{T}_{1 / 2 \text { elim }}$ (as already mentioned) and consequently the estimates of $\mathrm{AUC}_{0-\infty}$, as $\mathrm{AUC}_{0-\infty}=\mathrm{AUC}_{\mathrm{t}}+\mathrm{C}_{\mathrm{t}} / \lambda_{\mathrm{z}}$.

The parameter usually accepted to measure the absorbed drug amount is the AUC, which is proportional to the drug's absorbed fraction, provided its elimination process be linear. However, many times this process is not linear or can be modified by the excipient, making the elimination not constant. Therefore, equal AUCs are not a sufficient proof that the absorbed fractions are equal, even in a linear elimination process. ${ }^{18}$ Due to that, other parameters have been proposed for these studies. ${ }^{19-21}$

Other questionable aspect is whether the pharmacological bioequivalence is a measure of the therapeutic equivalence of both products, i.e., the absence of pharmacological bioequivalence necessarily would indicate a lack of therapeutic equivalence ${ }^{22}$

\section{Acknowledgments}

To the National Research Council (CNPq); the Association Fund of Incentive to Psychopharmacology (AFIP) for their financial sponsoring.
7. Perry PJ, Alexander B. Dosage and serum levels. In: Johnson FN. Depression and mania: modern lithium therapy. Oxford: IRL Press; 1987. p. 67-73.

8. Lesko LT. Bioavailability and bioequivalence of modified release dosage forms: general concepts. In: Blume HH, Midha KK. BioInternational 2: bioavailability, bioequivalence and pharmacokinetics studies; international conference of F.I.P. Munich: Medpharm Scientific Publ; 1994. p. 35-43.

9. Cooper TB, Simpson GM, Lee JH, Bergner PE. Evaluation of a slow-release lithium carbonate formulation. Am J Psychiatr 1978;135:917-22.

10. Arancíbia A, Flores P, Pezoa R. Steady state lithium concentrations with conventional and controlled release formulations. Lithium 1990; 1:237-9.

11. Kirkwood CK, Wilson SK, Hayes PE, Barr WH, Sarkar MA, Ettigi PG. Single-dose bioavailability of two extended-release lithium carbonate products. Am J Hosp Pharm 1994;51:486-9. 
12. Storpirtis S, Ferraz HG, Porta V, Consiglieri VO, Ting HC. Relatório técnico referente ao projeto de pesquisa: "Avaliação da bioequivalência de formulações de liberação controlada de carbonato de lítio"; 1996.

13. First MB, Spitzer RL, Gibbon M, Willians JBW. Structured clinical interview for DSM IV axis I disorders - non-patient edition (SCID- I/ NP version 2.0). New York: Biometrics research department; 1996.

14. U.S. Food and Drug Administration (FDA). Center for drug evaluation and Research. - Guidance for industry. In vivo bioequivalence studies based on population and individual bioequivalence approaches: draft guidance. [monography on line]. Rockville (MD): U.S. Department of Health and Human Services. Food and Drug Administration; 1997. Available from <URL:http://www.fda.gov/cder/guidance/index/htm [cited 1997 October 12].

15. United States pharmacopoeia. 23th ed. Rockville: United Pharmacopeial Convention; 1995.

16. Ministério da Saúde. Resolução n. 391, 9 ag. 1999. Regulamento técnico para medicamentos genéricos. Brasília (DF): Diário Oficial, 1999. n. 152. p. 62-9. seção 1.

17. Pidgen AW. Statistical aspects of bioequivalence: a review. Xenobiotica 1992;22:881-93.

18. Farolfi M, Powers JD, Rescigno A. On the determination of bioequivalence. Pharmacol Res 1999;39:1-4.

19. Schulz HU, Steinijans VW. Striving for standards in bioequivalence assessment: a review. Int $\mathrm{J}$ Clin Pharmacol Ther Toxicol 1992;30(Suppl 1):1-6.

20. Steinijans VW, Hauschke D, Jonkman JHG. Controversies in bioequivalence studies. Clin Pharmacokinet 1992;22:247-53.
21. U.S. Food and Drug Administration (FDA). Center for drug evaluation and Research. - Guidance for industry. Mean, population and individual approaches to establishing bioequivalence: draft guidance. [monography on line]. Rockville (MD): U.S. Department of Health and Human Services. Food and Drug Administration; 1999. Available from <URL:http://www.fda.gov/cder/guidance/index/ htm [cited 1999 Aug. 9].

22. Tucker GT, Rostami-Hodjegan A, Jackson PR. Bioequivalence: a measure of therapeutic equivalence? In: Blume HH, Midha KK. Biointernational 2: bioavailability, bioequivalence and pharmacokinetics studies; International conference of F.I.P. Munich: MedPharm Scientific Publ; 1994. p. 35-43.

\section{Correspondence:}

\section{Helena M. Calil}

Rua Botucatu, 862, $1^{\circ}$ andar, Vila Clementino

04023-062 São Paulo, SP, Brasil

Tel.: (0xx11) 5539-0155

Fax:(0xx11)5572-5092

E-mail:hmcalil@psicobio.epm.br 